\title{
Fører mobbing til helseplager?
}

Vi har lang tradisjon i Norge for å prioritere trygge arbeidsmiljøer - man skal ikke bli syk av å gå på jobb. Dette har også en juridisk side: Bestemmelsene i arbeidsmiljøloven gir arbeidsgiver et betydelig ansvar for å sikre at arbeidstakerne har «full trygghet mot fysiske og psykiske skadevirkninger» (1).

Sunn fornuft tilsier at mobbing er psykisk belastende. At det å bli mobbet dermed kan utløse depressive reaksjoner og andre psykiske helseplager, virker plausibelt. Dessuten har en rekke undersøkelser vist klar sammenheng mellom mobbing og psykiske helseproblemer. De som svarer ja på spørsmålet om de er utsatt for mobbing på jobben, oppgir også ofte å ha psykiske helseplager (2).

Men dette kan problematiseres. For det første kan det godt hende at årsak-virkning-forholdet er omvendt - at personer med psykiske plager er mer utsatt for mobbing enn andre. Undersøkelser der folk blir spurt én gang både om mobbing og psykiske plager - tverrsnittsundersøkelser - gir ikke svar på om det var mobbingen eller helseproblemene som kom først.

Ved å følge de samme menneskene over tid kan man avdekke om mobbingen fant sted før eller etter at folk ble syke. Slike longitudinelle studier er den klassiske måten å lete etter årsakssammenhenger på, så sant det ikke er mulig å utføre kontrollerte eksperimenter. For eksempel - det meste vi mener å vite om helseeffekter av forskjellige typer kosthold, stammer fra undersøkelser der man har fulgt en kohort av personer over tid og undersøkt matvaner og helsestatus på to eller flere tidspunkter. Det optimale hadde vært å gjennomføre randomiserte forsøk, slik vi gjør med legemidler. Men det å utsette forsøkspersoner for mobbing er ikke etisk forsvarlig, naturligvis, og det å få forsøkspersoner til å holde seg til et gitt kosthold er vanskelig, særlig over tid.

I dette nummer av Tidsskriftet presenterer Nielsen og medarbeidere en oppdatert systematisk oversikt over problemstillingen: Hva viser forskningen om årsakssammenhengen mellom mobbing på arbeidsplassen og helseplager (3)? De har lett grundig og systematisk etter longitudinelle studier der forekomsten av mobbing og helseplager ble målt på minst to forskjellige tidspunkter. Videre har de slått sammen resultater fra de enkelte studiene i én kvantitativ samleanalyse - metaanalyse.

Det er særlig to fordeler med denne metoden (4). For det første blir den statistiske «styrken» langt større enn i én studie, fordi tallgrunnlaget blir større. Dermed kan det avdekkes sammenhenger man ellers ikke ville sett. Et av de mest kjente eksemplene på dette gjaldt bruk av kortikosteroider til kvinner ved truende prematur fødsel. Først etter at resultatene fra de foreliggende studiene ble slått sammen i en metaanalyse, ble det klart for alle at behandlingen ga økt overlevelse for barna (5). En grafisk fremstilling av denne metaanalysen pryder logoen til Cochrane-samarbeidet.

Den andre fordelen med metaanalyser er at de forskjellige studiene som inngår, gjerne omfatter forskjellige populasjoner. Dermed kan resultatene være mer generaliserbare enn resultatene fra én enkelt studie. Og hvis resultatene spriker (heterogenitet), er det i seg selv en viktig observasjon som krever en forklaring. Hvorfor var A så klart assosiert med B i noen studier, men ikke i andre? Graden av sammenheng mellom mobbing og senere helseplager varierte mye på tvers av studiene som inngår i metaanalysen til Nielsen og medarbeidere. Én mulig forklaring er at definisjonen av «mobbing» og «psykisk helseplage» varierte. Hva som menes med «mobbing», er vesentlig for fortolkningen av denne type studier.

Tall kan forlede, ikke minst gjelder dette for metaanalyser. Det er alltid verdt å minne om at resultater fra slike analyser ikke er bedre enn studiene som ligger til grunn. Selv om Nielsen og medarbeidere fant en statistisk overbevisende sammenheng mellom mobbing og senere psykiske helseplager i sin metaanalyse, er de forsiktige med å konkludere. Det skyldes i første rekke at studiene de baserer seg på er observasjonelle - ikke eksperimentelle. Dermed vil det alltid være usikkerhet knyttet til om det er faktiske årsakssammenhenger man observerer, eller om det er andre forhold (tredjevariabler) som forårsaker at noen er mer utsatt både for mobbing og senere psykiske helseplager. Denne problemstillingen er velkjent fra kostholdsforskningen: Er det grønnsakene som holder folk friske, eller blir vi lurt til å tro det fordi grønnsakselskerne røyker mye mindre enn andre?

Én måte å forsøke å røyke ut en eventuell årsakssammenheng på er å se om det foreligger et dose-respons-forhold. Blir helsen jevnt bedre jo mer grønnsaker folk spiser? Dersom man fant at risikoen for helseplager er høyere for dem som har vært utsatt for alvorligere former for mobbing, ville det være en styrking av dokumentasjonen for at det er snakk om en årsakssammenheng (6). Eller man kan mene at årsak-virkning-forholdet her er så plausibelt at det ikke er behov for ytterligere dokumentasjon.

\section{Atle Fretheim}

atle.fretheim@kunnskapssenteret.no

Atle Fretheim (f. 1968) er forskningsleder ved Nasjonalt kunnskapssenter for helsetjenesten og førsteamanuensis ved Institutt for helse og samfunn, Universitetet i Oslo. Han har arbeidet med forskning om effekter av tiltak i helsetjenesten i 15 år.

Forfatter har fylt ut ICMJE-skjemaet og oppgir ingen interessekonflikter.

\section{Litteratur}

1. LOV 2005-06-17 nr. 62: Lov om arbeidsmiljø, arbeidstid og stillingsvern mv. (arbeidsmiliøloven). §§ 1-1. http://Lovdata.no/dokument/NL/lov/ 2005-06-17-62\#KAPITTEL 1 (18.5.2014).

2. Nielsen MB, Einarsen S. Outcomes of exposure to workplace bullying: A metaanalytic review. Work Stress 2012; 26: 309-32.

3. Nielsen MB, Magerøy N, Gjerstad J et al. Mobbing i arbeidslivet og senere helseplager. Tidsskr Nor Legeforen 2014: 134: 1233-8.

4. Smedslund G. Metaanalyse. Norsk Epidemiologi 2013; 23: 147-9. www.ntnu.no/ojs/index.php/norepid/article/view/1636/1524 (18.5.2014).

5. Crowley P, Chalmers I, Keirse MJ. The effects of corticosteroid administration before preterm delivery: an overview of the evidence from controlled trials. Br J Obstet Gynaecol 1990; 97: 11-25.

6. Schünemann H, Hill S, Guyatt $\mathrm{G}$ et al. The GRADE approach and Bradford Hill's criteria for causation. J Epidemiol Community Health 2011; 65: 392-5. 